\title{
Relationship between the degree of illness acceptance and depression, anxiety in women with breast cancer and men with colorectal cancer
}

\begin{abstract}
Introduction. Breast and colorectal cancer are often the cause of depressive disorders and anxiety. The aim of this study was to verify the hypothesis that as the level of illness acceptance increases, the level of anxiety and depression decreases.

Material and methods. The study involved 40 women aged 21-74 years, diagnosed with breast cancer and 40 men aged 22-85 years, diagnosed with colorectal cancer . In the study, Beck Depression Inventory, Acceptance of Illness Scale, mini-Mental Adjustment to Cancer (Mini-MAC) Scale and a questionnaire (respondent's particulars of own authorship) were used.

Results. Among men, the level of illness acceptance was low in $52.5 \%$, medium in $20 \%$, high in $27.5 \%$ of patients, whereas among women $-85 \%, 10 \%$ and $5 \%$ respectively. In the group of men, depression was not found in $40 \%$, mild depression in $15 \%$, moderate depression in $25 \%$ and severe depression in $20 \%$ of patients, the mean value of the level of depression was $16.7 \pm 11.2$; among women $-2.5 \%, 2.5 \%$, $5 \%$ and $90 \%$ of respondents respectively, the mean value was $34.4 \pm 7.8$. Among men, the mean values of anxiety absorption were $18.13 \pm 5.69$, helplessness/hopelessness $-16.95 \pm 6.03$, destructive style $35.08 \pm 11.53$, whereas the mean values among women were $26 \pm 3,02,22,6 \pm 2,28$ and 48,63 $\pm 5,13$ respectively. Significant negative correlations between the degree of illness acceptance and depression/ anxiety were shown, with absolute values of correlation coefficients being higher in women.

Conclusions. Women diagnosed with breast cancer show the low level of illness acceptance, high level of anxiety and often suffer from depression, while men diagnosed with colorectal cancer show the average level of illness acceptance and anxiety as well as less often suffer from depression.
\end{abstract}

Palliat Med Pract 2020; 14, 3: 141-148

Key words: cancer, depression, anxiety, breast cancer, colorectal cancer

\section{Introduction}

Cancer is the second cause of death in Poland, with approximately 96,000 patients dying each year, which results from population ageing and the widespread exposure of the population to carcino- gens related to i.a. a lifestyle. The highest rate of increase in morbidity and mortality due to the illness shows colorectal cancer which is the second most common cancer in women and men. The factors contributing to the risk of the disease include i.a. improper diet and lack of exercise [2]. According to

\footnotetext{
Address for correspondence:

Monika Wardas

Beskid Oncology Center - Municipal Hospital John Paul II

ul. Wyzwolenia 18, 43-300 Bielsko-Biała

e-mail: wardasmonika3@gmail.com
}

Palliative Medicine in Practice 2020; 14, 3, 141-148

Copyright (c) Via Medica, ISSN 2545-0425

DOI: $10.5603 /$ PMPI.2020.0015 
the Polish National Cancer Registry, the incidence of colorectal cancer in Poland in 2013 was 17,000 people, including 7,500 women and 9,500 men. The mortality due to colorectal cancer in Poland is higher compared to the EU countries and is characterised by an upward trend [3]. Breast cancer is the most common cancer among women in the Polish population. In 2014, 17,379 women suffered from breast cancer, whereas in men it is rare and constitutes $1 \%$ of breast cancer cases [4]. In 2017, breast cancer was diagnosed in 18,529 women, whereas colorectal cancer affected 5,832 men and 5,073 women $[5,6]$.

Breast and colorectal cancers are one of the main causes of depression and comorbid disorders. Depression is defined as a mood and emotional disorder accompanied by malaise, depressed mood and depression [7]. Depression often occurs in patients suffering from cancers and endocrine disorders. The WHO forecasts indicate that in 2020 depression will be one of the main causes of disability and the second most common diagnosis after cardiovascular diseases $[8,9]$. Anxiety is an emotional state caused by internal or external factors, which precedes the risk; therefore, it is important for the patient to accept the disease, especially accept themselves as a patient, often for the rest of their life $[10,11]$.

Cancer often causes fear and anxiety as it is usually unexpected, frequently irreversible, often of unknown aetiology and life-threatening [12]. Some patients associate cancer with pain and side effects of treatment, such as hair loss and emesis, which can cause emotional responses, mainly anxiety [13]. Accurate assessment of depressive disorders and anxiety may provide effective assistance to patients and improve treatment outcomes [14]. Prolonged sadness and negative thinking may result in lack of willingness to fight cancer. The diagnosis of breast and colorectal cancer is often a source of stress that accompanies the patient from the moment of information about the diagnosis to the end of treatment, and often longer. Stress associated with the treatment frequently does not disappear but persists and sometimes intensifies after the end of anticancer treatment. The response to cancer depends on individual personality traits such as the ability to cope with stressful situations. The attitude towards the disease, a degree of confidence in medical personnel and acceptance of the treatment proposed as well as the level of illness acceptance are the factors affecting the well-being of patients and success of therapy [15]. The aim of this study was to verify the research hypothesis which assumes that as the level of illness acceptance increases, the level of anxiety and depression decreases.

\section{Material and methods}

The research was conducted in the period from 1 September 2019 to 31 December 2019 among patients diagnosed with colorectal and breast cancer, hospitalised in the Department of Oncology for chemotherapy. The study was approved by the Bioethics Committee and conducted in accordance with the Declaration of Helsinki. The inclusion criteria for the study included the diagnosis of breast or colorectal cancer, age from 18 years, voluntary and informed consent to participate in the survey. The exclusion criteria were: diagnosis other than breast or colorectal cancer, lack of voluntary consent to participate in the survey, severe general condition. The study was questionnaire-based, all patients were informed about the aim, method and possibility of resignation at each stage of the research. One hundred patients were eligible for the study, but after verification 20 patients were rejected due to incorrectly filled in questionnaires. The analysis included 80 patients: 40 women diagnosed with breast cancer and 40 men diagnosed with colorectal cancer. The following research tools were used:

The mini-Mental Adjustment to Cancer (Mini-MAC) Scale by Watson et al. is used to assess the patient's response to the diagnosis of cancer and changes occurring during the treatment and rehabilitation. The tool consists of 29 statements that measure 4 strategies for coping with cancer: fighting spirit, anxiety absorption, positive reappraisal and helplessness/hopelessness. Two of the four strategies present constructive style, the other two - destructive style. By obtaining the results of anxiety and depressive states, only two out of four strategies were considered at preparation of the analysis: anxiety absorption and helplessness/hopelessness [16].

The Acceptance of Illness Scale (AIS) by Felton et al., adapted by Juczyński, is used to assess the degree of illness acceptance in chronic disease entities. AIS includes 8 questions concerning the negative effects of ill health to assess the acceptance of limitations caused by the health situation; the results are in the range of 8-40 points. A high score means the illness acceptance, whereas the lower the score, the lower acceptance of the illness [17].

The Beck Depression Inventory (BDI) by Beck et al. is a self-report tool for screening diagnosis of the symptoms of depression in the subject and includes 21 items; the results are classified into 4 categories: 1 - no depression, 2 - mild depression, 3 - moderate depression, 4 - severe depression. BDI is a tool to measure the severity of depression in psychiatric patients [18]. 
The author's questionnaire - a statistical part (respondent's particulars) was used to collect basic information about the patients: age, gender, education and place of residence.

\section{Statistical methods}

Correlation analysis was applied to analyse the results and the Pearson correlation coefficients calculated were verified with Student's $t$ test. AIS was taken into account as an independent variable, whereas anxiety and depression measures were dependent variables, the levels of which were determined on the basis of selected research tools. In addition, mean values and standard deviations (SD) were calculated and the results were classified according to the applicable standards for the scales used.

\section{Results}

The sociodemographic characteristics of the surveyed patients are presented in Table 1 . The age of men diagnosed with colorectal cancer ranged from 22-85 years with the average of $57.6 \pm 14.6$ years, while among women diagnosed with breast cancer $-21-74$ years with the average of $48.4 \pm 13.4$ years. The majority of men lived in the countryside (40\%), whereas $37.5 \%$ of women lived in the town with 50-100 thousand inhabitants. In the group of patients with colorectal cancer, $32.5 \%$ of men had vocational education and $27.5 \%$ of men had higher education. Among breast cancer patients, $27.5 \%$ of women had secondary education and $42.5 \%$ of women had higher education. More than $35 \%$ of men and $30 \%$ of women were married, $20 \%$ of men and $27.5 \%$ of women were single, $72.5 \%$ of men and $65 \%$ of women declared that they had children. In the group of men, $42.5 \%$ considered their financial situation to be sufficient, while $45 \%$ of women considered their financial situation to be bad. Men (32.5\%) received the greatest support from the environment, while most women received support from friends $(27.5 \%)$.

Table 2 presents clinical data of the studied patients. Patients diagnosed with colorectal cancer were hospitalised 11-20 times (30\%) in the Department of Oncology, the same percentage of men $(30 \%)$ declared that they were then more than 20 times in the Department of Oncology to administer chemotherapy. Thirty-five percent of women were admitted to the Department of Oncology for the first time. Thirty-five percent of men declared that the disease lasted 13-24 months, while less than 5 months of the disease duration was reported by $37.5 \%$ of women. Among men, $37.5 \%$ of them frequently felt pain, $35.5 \%$ - from time to time. The majority of women (57.5\%) frequently suffered from pain most often caused by lymphoedema (52.5\%). Eighty-two point five percent of men experienced difficulties in everyday life, in the group of women this problem was reported by $85 \%$ of women, while a depressed mood was felt by $45 \%$ of men and $57.5 \%$ of women. A frequent state of anxiety was declared by $42.5 \%$ of men, while $25 \%$ considered it to occur from time to time. In the majority (52.5\%) of women, the state of anxiety was frequent. Both men (95\%) and women (87.5\%) received accurate information on chemotherapy.

Chemotherapy was applied in $37.5 \%$ of men and $60 \%$ of women. Men often felt anxious (35\%) and sad $(40 \%)$, they gave evenly distributed answers in terms of anxiety: I am not afraid (30\%), I am often afraid $(30 \%)$, I experience constant anxiety $(30 \%)$, whereas women felt constantly anxious ( $40 \%)$, they were often sad (35\%) and constantly experienced anxiety (37.5\%).

Table 3 presents the characteristics of the level of illness acceptance by respondents. The low level of illness acceptance was found in $52.5 \%$ of men, while in the group of women $-85 \%$ of the respondents. Average illness acceptance was shown by $20 \%$ of men and $10 \%$ of women, whereas high acceptance of the illness was shown by $27.5 \%$ of men and $5 \%$ of women. The overall AIS was $21.5 \pm 9.1$ on average for men, while among women the mean value was $13.8 \pm 5.8$

Table 4 shows the characteristics of the depression level according to BDI. No depression was found in $40 \%$ of men, no mild depression in $15 \%$, no moderate depression in $25 \%$ and no severe depression in $20 \%$ of patients, the mean value of depression was $16.7 \pm 11.2$. Among women, severe depression was found in $90 \%$ of the respondents, $2.5 \%$ of them showed no symptoms of depression, the mean value was $34.4 \pm 7.8$. Lack of depression may indicate a temporary deterioration of the patient's mental state which is caused by current events in life.

Mean values and standard deviations for selected Mini-MAC scale strategies were shown in Table 5. In the group of colorectal cancer patients the mean values of anxiety absorption were $18.13 \pm 5.69$, helplessness/hopelessness $-16.95 \pm 6.03$, destructive style $-35.08 \pm 11.53$, whereas in the group of women with breast cancer the mean values of anxiety absorption were $26 \pm 3.02$, helplessness/hopelessness $-22.6 \pm 2.28$, destructive style $-48.63 \pm 5.13$.

Table 6 presents the results of correlation analysis characterising the relationship between the degree of illness acceptance and depression, anxiety among patients with breast and colorectal cancer. All the correlation coefficients determined are negative, and the significance level is $p<0,001$. 
Table 1. Sociodemographic data of the surveyed patients

\begin{tabular}{|c|c|c|c|}
\hline Characteristics & \multicolumn{2}{|c|}{ Colorectal cancer } & \multirow{3}{*}{$\begin{array}{l}\text { Breast cancer } \\
48.4 \\
13.4\end{array}$} \\
\hline Age & 57.6 & \multirow{2}{*}{$\begin{array}{l}\text { Min-Max } \\
\text { 22-85 }\end{array}$} & \\
\hline (years) & 14.6 & & \\
\hline & $\mathrm{n}$ & $\%$ & $\mathrm{n}$ \\
\hline \multicolumn{4}{|l|}{ Place of residence } \\
\hline Countryside & 16 & $40.0 \%$ & 13 \\
\hline Town $<50$ thousand inhabitants & 9 & $22.5 \%$ & 3 \\
\hline Town of $50-100$ thousand inhabitants & 10 & $25.0 \%$ & 15 \\
\hline City $>100$ thousand inhabitants & 5 & $12.5 \%$ & 9 \\
\hline \multicolumn{4}{|l|}{ Education } \\
\hline Primary & 6 & $15.0 \%$ & 5 \\
\hline Vocational & 13 & $32.5 \%$ & 7 \\
\hline Secondary & 10 & $25.0 \%$ & 11 \\
\hline Higher & 11 & $27.5 \%$ & 17 \\
\hline \multicolumn{4}{|l|}{ Marital status } \\
\hline Single & 8 & $20.0 \%$ & 11 \\
\hline Married & 14 & $35.0 \%$ & 12 \\
\hline Divorced & 9 & $22.5 \%$ & 9 \\
\hline Widow/er & 9 & $22.5 \%$ & 8 \\
\hline \multicolumn{4}{|l|}{ Children } \\
\hline Yes & 29 & $72.5 \%$ & 26 \\
\hline No & 11 & $27.5 \%$ & 14 \\
\hline \multicolumn{4}{|l|}{ Number of children } \\
\hline 1 & 10 & $34.5 \%$ & 14 \\
\hline $2-3$ & 12 & $41.4 \%$ & 8 \\
\hline $4-5$ & 7 & $24.1 \%$ & 4 \\
\hline$>5$ & 0 & $0.0 \%$ & 0 \\
\hline \multicolumn{4}{|l|}{ Age of children } \\
\hline$<10$ years & 5 & $17.2 \%$ & 8 \\
\hline $11-19$ years & 4 & $13.8 \%$ & 8 \\
\hline $20-29$ years & 2 & $6.9 \%$ & 3 \\
\hline$>29$ years & 18 & $62.1 \%$ & 7 \\
\hline \multicolumn{4}{|l|}{ Housing situation } \\
\hline I live alone & 18 & $45.0 \%$ & 13 \\
\hline I live with children & 3 & $7.5 \%$ & 13 \\
\hline I live with my wife/husband & 7 & $17.5 \%$ & 3 \\
\hline I live with my family & 12 & $30.0 \%$ & 11 \\
\hline \multicolumn{4}{|l|}{ Financial situation } \\
\hline Poor & 13 & $32.5 \%$ & 18 \\
\hline Sufficient & 17 & $42.5 \%$ & 11 \\
\hline Good & 5 & $12.5 \%$ & 6 \\
\hline Very good & 5 & $12.5 \%$ & 5 \\
\hline \multicolumn{4}{|l|}{ Support from the environment } \\
\hline From family & 9 & $22.5 \%$ & 9 \\
\hline From friends & 3 & $7.5 \%$ & 11 \\
\hline From partner & 5 & $12.5 \%$ & 4 \\
\hline From members of medical team & 5 & $12.5 \%$ & 6 \\
\hline All of the above & 13 & $32.5 \%$ & 7 \\
\hline I have no support & 5 & $12.5 \%$ & 3 \\
\hline
\end{tabular}


Table 2. Clinical characteristics of the patients surveyed

$\begin{array}{lll}\text { Characteristics } & \begin{array}{l}\text { Colorectal } \\ \text { cancer }\end{array} & \begin{array}{l}\text { Breast } \\ \text { cancer }\end{array} \\ \text { n } \% & n\end{array}$

Frequency of visits in the Department of Oncology and Hematooncology

\begin{tabular}{|c|c|c|c|}
\hline Once & 3 & $7.5 \%$ & 14 \\
\hline $2-5 \%$ & 7 & $17.5 \%$ & 3 \\
\hline 6-10 times & 6 & $15.0 \%$ & 5 \\
\hline 11-20 times & 12 & $30.0 \%$ & 8 \\
\hline$>20$ times & 12 & $30.0 \%$ & 10 \\
\hline \multicolumn{4}{|c|}{ Duration of oncological disease } \\
\hline$<5$ months & 11 & $27.5 \%$ & 15 \\
\hline 5-12 months & 6 & $15.0 \%$ & 6 \\
\hline 13-24 months & 14 & $35.0 \%$ & 6 \\
\hline$>24$ months & 9 & $22.5 \%$ & 13 \\
\hline \multicolumn{4}{|l|}{ Prevalence of pain } \\
\hline Often & 15 & $37.5 \%$ & 23 \\
\hline Most of the time & 7 & $17.5 \%$ & 3 \\
\hline From time to time & 14 & $35.0 \%$ & 13 \\
\hline Never & 4 & $10.0 \%$ & 1 \\
\hline \multicolumn{4}{|c|}{ Type of complaints in breast cancer } \\
\hline Lymphadenopathy & & & 14 \\
\hline Breast-skin ulceration & & & 3 \\
\hline Nipple leakage & & & 0 \\
\hline Lymphoedema & & & 21 \\
\hline Neuralgia & & & 1 \\
\hline All of the above & & & 1 \\
\hline Others & & & 0 \\
\hline No ailments & & & 0 \\
\hline \multicolumn{4}{|c|}{ Type of complaints in colorectal cancer } \\
\hline Constipation/diarrhoea & 1 & $2.5 \%$ & \\
\hline Abdominal pains & 0 & $0.0 \%$ & \\
\hline Nausea and vomiting & 6 & $15.0 \%$ & \\
\hline All of the above & 0 & $0.0 \%$ & \\
\hline Others & 0 & $0.0 \%$ & \\
\hline No ailments & 33 & $82.5 \%$ & \\
\hline \multicolumn{4}{|l|}{ Difficulties in daily life } \\
\hline Yes & 33 & $82.5 \%$ & 34 \\
\hline No & 7 & $17.5 \%$ & 6 \\
\hline \multicolumn{4}{|l|}{ Prevalence of sad mood } \\
\hline Often & 18 & $45.0 \%$ & 23 \\
\hline Most of the time & 5 & $12.5 \%$ & 8 \\
\hline From time to time & 13 & $32.5 \%$ & 8 \\
\hline
\end{tabular}

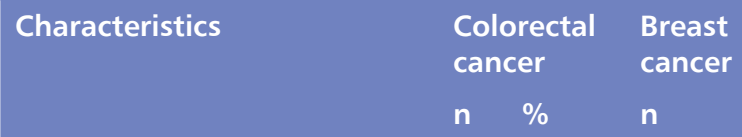

Prevalence of anxiety

\begin{tabular}{llll}
\hline Often & 17 & $42.5 \%$ & 21 \\
\hline Most of the time & 6 & $15.0 \%$ & 11 \\
\hline From time to time & 10 & $25.0 \%$ & 7 \\
\hline Never & 7 & $17.5 \%$ & 1
\end{tabular}

Obtaining accurate information on chemotherapy treatment

\begin{tabular}{llll}
\hline Yes & 38 & $95.0 \%$ & 35 \\
\hline No & 2 & $5.0 \%$ & 5
\end{tabular}

Type of treatment in the course of breast / colorectal cancer

\begin{tabular}{llll}
\hline Surgical treatment & 13 & $32.5 \%$ & 10 \\
\hline Radiotherapy & 3 & $7.5 \%$ & 0 \\
\hline Hormone therapy & 1 & $2.5 \%$ & 1 \\
\hline Immunotherapy & 0 & $0.0 \%$ & 0 \\
\hline Chemotherapy & 15 & $37.5 \%$ & 24 \\
\hline Combination therapy & 8 & $20.0 \%$ & 5
\end{tabular}

Response to existing treatment

\begin{tabular}{llll}
\hline Very good & 5 & $12.5 \%$ & 3 \\
\hline Good & 20 & $50.0 \%$ & 5 \\
\hline Poor & 11 & $27.5 \%$ & 28 \\
\hline Very poor & 4 & $10.0 \%$ & 4
\end{tabular}

Attitude to calm

$\begin{array}{llll}\text { I feel calm } & 13 & 32.5 \% & 1\end{array}$

$\begin{array}{llll}\text { I often feel anxious } & 14 & 35.0 \% & 12\end{array}$

I feel constantly anxious $\quad 8 \quad 20.0 \% \quad 16$

I feel anxious all the time $\quad 5 \quad 12.5 \% \quad 11$

Attitude to sadness

I am not sad $\quad 13 \quad 32.5 \% \quad 2$

$\begin{array}{llll}\text { I often feel sad } & 16 & 40.0 \% & 14\end{array}$

I am constantly experiencing $\quad \begin{array}{lll}6 & 15.0 \% & 13\end{array}$ sadness that I can't get rid of

I am sad all the time and it's $\quad 5 \quad 12.5 \% \quad 11$ unbearable

Attitude to anxiety

\begin{tabular}{|llll|}
\hline I am not afraid & 12 & $30.0 \%$ & 3 \\
\hline I am often afraid & 12 & $30.0 \%$ & 8 \\
\hline $\begin{array}{l}\text { I am constantly experiencing } \\
\text { anxiety }\end{array}$ & 12 & $30.0 \%$ & 15 \\
\hline $\begin{array}{l}\text { A strong fear accompanies me } \\
\text { all the time }\end{array}$ & 4 & $10.0 \%$ & 14 \\
\hline
\end{tabular}


Table 3. Characteristics of the level of illness acceptance by the surveyed patients

\begin{tabular}{llll} 
Scale & \multicolumn{2}{l}{ Colorectal cancer } & Breast cancer \\
& $n$ & $\%$ & $n$ \\
Low (8-18) & 21 & $52.5 \%$ & 21 \\
\hline Average (19-28) & 8 & $20.0 \%$ & 8 \\
\hline High (29-40) & 11 & $27.5 \%$ & 11 \\
& $\begin{array}{l}\text { Overall level of } \\
\text { illness acceptance } \\
\text { Mean }\end{array}$ & \\
& SD & Mean value \\
& 21.5 & 9.1 & 13.8 \\
\hline
\end{tabular}

Table 4. Characteristics of depression level according to BDI

\begin{tabular}{|c|c|c|c|}
\hline \multirow[t]{2}{*}{ Scale } & \multicolumn{2}{|c|}{ Colorectal cancer } & \multirow{2}{*}{$\begin{array}{l}\text { Breast } \\
\text { cancer } \\
\mathbf{n}\end{array}$} \\
\hline & $\mathbf{n}$ & $\%$ & \\
\hline No depression (0-10) & 16 & $40.0 \%$ & 1 \\
\hline Mild depression (11-19) & 6 & $15.0 \%$ & 1 \\
\hline $\begin{array}{l}\text { Moderate depression } \\
(20-25)\end{array}$ & 10 & $25.0 \%$ & 2 \\
\hline \multirow[t]{4}{*}{$\begin{array}{l}\text { Severe depression } \\
(26-63)\end{array}$} & 8 & $20.0 \%$ & 36 \\
\hline & \multicolumn{2}{|c|}{$\begin{array}{l}\text { Overall level of } \\
\text { depression }\end{array}$} & \\
\hline & $\begin{array}{l}\text { Mean } \\
\text { value }\end{array}$ & SD & $\begin{array}{l}\text { Mean } \\
\text { value }\end{array}$ \\
\hline & 16.7 & 11.2 & 34.4 \\
\hline
\end{tabular}

\section{Discussion}

In our study, all correlation coefficients were negative and statistically significant $(p<0.001)$ in the correlation analysis between the degree of illness acceptance and depression, anxiety among patients with breast and colorectal cancer. In addition, it was found that the higher the degree of illness acceptance, the better the patients cope with depression and anxiety. Patients with a low level of cancer acceptance, especially during treatment with significant toxicity, require intensive therapeutic measures. Some patients accept the diagnosis, but the vast majority of them need time to accept and adapt to cancer. The results obtained confirm the research hypothesis that as the level of illness acceptance increases, the level of anxiety and depression decreases. Furthermore, it was found that women diagnosed with breast cancer experience depressive and anxiety states more strongly than men diagnosed with colorectal cancer. A high depression
Table 5. Mean values and standard deviations for selected Mini-MAC scale strategies

\begin{tabular}{llll} 
& $\begin{array}{l}\text { Anxiety } \\
\text { absorption }\end{array}$ & $\begin{array}{l}\text { Helplessness/ } \\
\text { /hopelessness }\end{array}$ & $\begin{array}{l}\text { Destructive } \\
\text { style }\end{array}$ \\
$\begin{array}{l}\text { Colorectal cancer } \\
\begin{array}{l}\text { Mean } \\
\text { value }\end{array}\end{array}$ & 18.13 & 16.95 & 35.08 \\
\hline SD & 5.69 & 6.03 & 11.53 \\
\hline $\begin{array}{l}\text { Breast cancer } \\
\begin{array}{l}\text { Mean } \\
\text { value }\end{array}\end{array} 26.00$ & 22.63 & 48.63 \\
\hline SD & 3.02 & 2.28 & 5.13 \\
\hline
\end{tabular}

Table 6. Results of the correlation analysis between AIS and the level of anxiety and depression

\begin{tabular}{llll} 
Scale & \multicolumn{2}{l}{$\begin{array}{l}\text { AIS } \\
\text { Colorectal cancer }\end{array}$} & $\begin{array}{l}\text { Breast } \\
\text { cancer }\end{array}$ \\
& $r$ & $p$ & $r$ \\
\hline $\begin{array}{l}\text { Anxiety absorption } \\
\text { (Mini-MAC) }\end{array}$ & -0.611 & $<0.001$ & -0.720 \\
\hline $\begin{array}{l}\text { Helplessness/hopeles- } \\
\text { sness (Mini-MAC) }\end{array}$ & -0.615 & $<0.001$ & -0.768 \\
\hline $\begin{array}{l}\text { Destructive style (Mini } \\
\text {-MAC) }\end{array}$ & -0.624 & $<0.001$ & -0.766 \\
\hline BDI & -0.603 & $<0.001$ & -0.622 \\
\hline
\end{tabular}

score in a group of women may be due to the effects of undesirable cytostatic drugs (including malaise, nausea, vomiting, hair loss, constipation, diarrhea).

As regards the degree of illness acceptance assessed by AIS, which describes negative consequences of the patient's ill health, both men with colorectal cancer and women with breast cancer were found to have a low level of illness acceptance, which means a sense of mental discomfort, lack of self-sufficiency and lowered self-esteem [19]. Moderate depression, which was found in the surveyed patients, suggests taking therapeutic measures, while severe depression, which was found in $90 \%$ of women treated for breast cancer, is a significant clinical problem, a threat to health and life, especially when suicidal thoughts occur. In such cases, quick psychiatric help, pharmacological therapy and hospitalisation are necessary [20]. Anxiety absorption reflects anxiety caused by cancer, which in the opinion of patients poses a threat, and signals coming from the body are interpreted as deterioration of health. The results of the strategy of helplessness/hopelessness indicate helplessness of patients, which may cause loss and passive giving in to the disease [21]. 
Cancer can cause anxiety and disbelief among patients and their relatives. The location of cancer (e.g. breast in women) and the consequences of treatment (e.g. artificial anus in patients with colorectal cancer) often result in discomfort in women and men; these are important factors that cause additional psychological burden for cancer patients [22]. Mental disorders may occur at any stage of treatment [23], and a frequent response to information about cancer is anxiety and depression [24].

Lack of knowledge of cancer can cause an unrealistic picture of the disease, sometimes associated with death. An attitude of protection against difficult information and not allowing it to be known, which may be accompanied by shock, anxiety, disbelief or anger (which reduce the body's energy resources, necessary to maintain homeostasis) may also dominate. Patients and relatives should have access to a psychologist - a psycho-oncologist who can provide support for patients and carers.

Anxiety states are an essential element of psychological autoanalysis of cancer. These feelings may negatively affect the patient's life and health when information about the disease is denied, not accepted by the patient, and negative thoughts as well as emotional attitude occurring in the course of the disease may sometimes take the form of depressive disorders, e.g. suicidal thoughts [25]. Lack of appetite, tiredness, mood swings or insomnia may be symptoms of developing depression [26]. Depression is often diagnosed in chronically ill patients and those with diagnosis of cancer [27].

In a study conducted in 1100 cancer patients, de Walden-Gałuszko et al. showed that $1 / 3$ of the patients had depressive disorders and $44.9 \%$ had anxiety-depressive maladaptive syndrome, while $17.7 \%$ had severe depression. Depressive disorders that occurred in the study group of patients were most common in women and young people [28]. Szwat et al. found the incidence of depression and limit states of depression in $30 \%$ of cancer patients receiving palliative care [29]. A key element is the illness acceptance. The patient's acceptance of the illness is phased and may be very difficult. Zauszniewski et al. considered the illness acceptance as mental reconciliation and adaptation to potential limitations, leading to interference of the changed psychophysical condition with the current lifestyle [30].

The limitations of this study are the small number of patients diagnosed with only two cancers (breast cancer and colorectal cancer); the inclusion of a heterogeneous group of patients in terms of the clinical severity of the disease; as well as different percentage of men and women treated with cytostatic drugs. Another limitation of the study was the lack of analysis of the influence of gender on the results regarding depression.

\section{Conclusions}

1. Negative correlations between the level of illness acceptance and anxiety/depression have been shown.

2. Women with breast cancer are more likely to show the low level of illness acceptance.

3. The level of depression and anxiety is higher in women with breast cancer compared to men diagnosed with colorectal cancer.

\section{Conflict of interests}

The author declares no conflict of interest.

\section{Funding}

This study has no funding.

\section{References}

1. Potrykowska A, Strzelecki Z, Szymborski J, Witkowski J. Zachorowalność i umieralność na nowotwory a sytuacja demograficzna Polski. Rządowa Rada Ludnościowa, Warsaw 2014.

2. Zdrowie priorytetem politycznym państwa - analiza i rekomendacje. Report of the Institute for Health Protection, Warsaw 2013.

3. Wyrwicz L, Gryglewicz J, Chrostowski Sz, Domańska-Sadynica M, Ambroziewicz B. Sytuacja pacjenta z jelitem grubego w Polsce - propozycja zmian. Warsaw 2013.

4. Didkowska J, Wojciechowska U. Nowotwory złośliwe w Polsce w 2013 roku. Centre of Oncology - M. SkłodowskaCurie Institute, Warsaw 2015.

5. http://onkologia.org.pl/nowotwory-zlosliwe-jelita-grubego-c18-21 (25 March 2020).

6. http://onkologia.org.pl/nowotwory-zlosliwe-piersi-c18 (25 March 2020).

7. Święcicki $Ł$. Depresje - definicja, klasyfikacje, przyczyny. Psychiatria w Praktyce Ogólnolekarskiej. 2002;(2): 151-159.

8. Mess E, Malewicz K, Lisowska A, et al. Występowanie depresji u pacjentów z nowotworem płuc. Onkol Pol. 2006;(9): 154-157.

9. Nowicki A, Rządkowska B. Depresja i lęk u chorych z nowotworami złośliwymi. Współcz Onkol. 2005;(9): 396-403.

10. Bilikiewicz A. ed. Psychiatria. PZWL, Warsaw 2006: 222594

11. Wrona-Polańska H. Zmiana samopercepcji w procesie adaptacji $w$ chorobie o niepomyślnej prognozie. Sztuka Leczenia. 1998;(4): 67-75.

12. Małyszczak K, Wróbel T, Mazur G, et al. Objawy lękowe i depresyjne u pacjentów leczonych na nowotwory hematologiczne. Psychiatria Pol. 2005;(39): 33-41.

13. Tomaszewska I. Psychologiczne aspekty depresji w chorobach nowotworowych. Psychoonkologia. 2000;(7): 9-18.

14. Mess E, Głuszyńska M, Lisowska A, et al. Ocena poziomu bólu i lęku u pacjentów z chorobą nowotworowa. Onkol Pol. 2009;(12): 154-161.

15. Juczyński Z. Narzędzia pomiaru w promocji i psychologii zdrowia. Pracownia Testów Psychologicznych Polskiego Towarzystwa Psychologicznego, Warsaw 2001: 168-174. 
16. Mini-Mac - Skala Przystosowania Psychicznego do Choroby Nowotworowej. Watson M., Law M., dos Santos M., Greer S., Baruch J., Bliss J., 167-168.

17. Juczyński Z. Narzędzia pomiaru w promocji i psychologii zdrowia. Pracownia Testów Psychologicznych Polskiego Towarzystwa Psychologicznego, Warsaw 2001: 168-174.

18. Beck AT, Ward CH, Mendelson M, et al. An Inventory for Measuring Depression. Archives of General Psychiatry. 1961; 4(6): 561, doi: 10.1001/archpsyc.1961.01710120031004.

19. Juczyński Z. Narzędzia pomiaru w promocji i psychologii zdrowia. Pracownia Testów Psychologicznych Polskiego Towarzystwa Psychologicznego, Warsaw 2001: 168-170.

20. Beck AT, Ward CH, Mendelson M, et al. An inventory for measuring depression. Arch Gen Psychiatry. 1961;(4): 53-63, doi: 10.1001/archpsyc.1961.01710120031004, indexed in Pubmed: 13688369.

21. Mini-Mac - Skala Przystosowania Psychicznego do Choroby Nowotworowej. Watson M., Law M., dos Santos M., Greer S., Baruch J., Bliss J., 168-178.

22. De Walden-Gałuszko KaG, Majkowicz M, Trzebiatowska I. Najczęstsze problemy psychiczne w ambulatoryjnej praktyce onkologicznej. Psychoonkologia. 1998;(2): 21-26.

23. Araszkiewicz A, Bartkowiak W, Starzec W. Zaburzenia lękowe w chorobie nowotworowej. Psychiatria w Praktyce Ogólnolekarskiej. 2004;(4): 157-166.
24. Tomaszewska I. Psychologiczne aspekty depresji w chorobach nowotworowych. Psychoonkologia. 2000;(7): 9-18.

25. Fryc-Martyńska J. Wsparcie społeczne jako forma pomocy w procesie zmagania się z krytycznymi wydarzeniami życiowymi. Wolontariusze Polskiego Towarzystwa Opieki nad Chorymi ze Stomią POL-ILKO. Psychoonkologia. 1997;(14): 99-102.

26. Guthrie E. Emotional disorder in chronic illness: psychotherapeutic interventions. Br J Psychiatry. 1996; 168(3): 265-273, doi: 10.1192/bjp.168.3.265, indexed in Pubmed: 8833678.

27. Katon WJ. Epidemiology and treatment of depression in patients with chronic medical illness. Dialog Clin Neuroscie. 2011; 13(1): 7-23, indexed in Pubmed: 21485743.

28. De Walden-Gałuszko W, Majkowicz M, Zdun-Ryżewska A. Zaburzenia przystosowania do choroby nowotworowej - trudności diagnostyczne zespołów depresyjnych. Psychoonkol. 2013;(1): 10-15.

29. Szwat B, Słupski W, Krzyżanowski D. Sposoby radzenia sobie $z$ chorobą nowotworową, a poczucie depresji i nasilenie bólu u chorych objętych opieka paliatywną. Piel Zdr Publ. 2011;(1): 35-51.

30. Zauszniewski JA, Bekhet AK, Lai CY, et al. Effects of teaching resourcefulness and acceptance on affect, behavior, and cognition of chronically ill elders. Issues Ment Health Nurs. 2007; 28(6): 575-592, doi: 10.1080/01612840701354547, indexed in Pubmed: 17613157. 


\section{Zależność między stopniem akceptacji} choroby a depresją i lękiem u kobiet

\section{$\mathrm{z}$ rakiem piersi oraz u mężczyzn z rakiem jelita grubego}

Artykuł jest tłumaczeniem pracy: Wardas M. Relationship between the degree of illness acceptance and depression, anxiety in women with breast cancer and men with colorectal cancer. Palliat. Med. Pract. 2020 tom 14, nr 3: 141-148. Należy cytować wersję pierwotną.

\section{Streszczenie}

Wstęp. Rak piersi i rak jelita grubego często są przyczyną zaburzeń depresyjnych i lękowych. Celem badania było zweryfikowanie hipotezy, według której w miarę wzrostu poziomu akceptacji choroby maleje poziom lęku i depresji.

Materiał i metody. Badaniem objęto 40 kobiet z rozpoznaniem rakiem piersi w wieku 21-74 lat i 40 mężczyzn z rozpoznaniem rakiem jelita grubego w wieku 22-85 lat. W badaniu zastosowano Skalę Depresji Becka, Skalę Akceptacji Choroby, Skalę Mini-MAC Przystosowania Psychicznego do Choroby Nowotworowej i ankietę - metryczkę własnego autorstwa.

Wyniki. Wśród mężczyzn poziom akceptacji choroby był niski u 52,5\%, średni u 20\%, wysoki u 27,5\% chorych, natomiast wśród kobiet, odpowiednio u 85\%, 10\% i 5\% badanych. W grupie mężczyzn depresji nie stwierdzono u 40\%, depresję łagodną u 15\%, depresję umiarkowaną u 25\% i depresję ciężką u $20 \%$ chorych, wartość średnia poziomu depresji wyniosła 16,7 $\pm 11,2$, wśród kobiet odpowiednio, u 2,5\%, 2,5\%, 5\% i 90\% badanych, wartość średnia wyniosła 34,4 $\pm 7,8$. Wśród mężczyzn wartości średnie zaabsorbowania lękowego wyniosły 18,13 $\pm 5,69$, bezradności - beznadziejności 16,95 $\pm 6,03$, stylu destrukcyjnego 35,08 $\pm 11,53$, natomiast wśród kobiet, wartości średnie wynosiły, odpowiednio: $26 \pm 3,02$, $22,6 \pm 2,28$ i $48,63 \pm 5,13$. Wykazano istotne ujemne korelacje pomiędzy stopniem akceptacji choroby a depresją i lękiem, przy czym wartości bezwzględne współczynników korelacji były większe w grupie kobiet. Wnioski. Kobiety z rozpoznaniem rakiem piersi wykazują niski poziom akceptacji choroby, wysoki poziom lęku i często depresję, natomiast mężczyźni z rozpoznaniem rakiem jelita grubego wykazują średni poziom akceptacji choroby i lęku oraz rzadziej depresję.

Palliat Med Pract 2020; 14, 3: 149-156

Słowa kluczowe: choroba nowotworowa, depresja, lęk, rak piersi, rak jelita grubego

\section{Adres do korespondencji:}

Monika Wardas

Beskidzkie Centrum Onkologii — Szpital Miejski im. Jana Pawła II

ul. Wyzwolenia 18, 43-300 Bielsko-Biała

e-mail: wardasmonika3@gmail.com 


\section{Wstęp}

Nowotwory stanowią drugą przyczynę zgonów w Polsce, rocznie umiera około 96000 chorych, co wynika z procesu starzenia się społeczeństwa, jak również z powszechnego narażenia populacji na czynniki rakotwórcze, związane między innymi ze stylem życia [1]. Największą dynamikę wzrostu zachorowań i zgonów z powodu choroby wykazuje rak jelita grubego, który jest drugim co do częstości występowania nowotworem u kobiet i mężczyzn. Do czynników sprzyjających zachorowania należą między innymi niewłaściwa dieta i brak ruchu [2]. Według Krajowego Rejestru Nowotworów liczba zachorowań na nowotwory jelita grubego w Polsce w 2013 roku wyniosła 17000 osób, z czego 7500 u kobiet oraz 9500 u mężczyzn. Umieralność z powodu raka jelita grubego w Polsce jest wyższa w porównaniu z krajami Unii Europejskiej i charakteryzuje się tendencją wzrostową [3]. Rak piersi jest najczęściej występującym nowotworem wśród kobiet polskiej populacji. W 2014 roku na raka piersi zachorowało 17379 kobiet, natomiast u mężczyzn jest rzadki i stanowi $1 \%$ zachorowań [4]. W 2017 roku raka piersi rozpoznano u 18529 kobiet, natomiast na raka jelita grubego zachorowało 5832 mężczyzn i 5073 kobiet $[5,6]$.

Rak piersi i rak jelita grubego stanowią jedną z głównych przyczyn depresji i zaburzeń współistniejących. Depresja definiowana jest jako zaburzenie nastroju i emocji, któremu towarzyszą złe samopoczucie, obniżony nastrój i przygnębienie [7]. Depresja często występuje u chorych na nowotwory i z zaburzeniami układu endokrynologicznego. Z prognoz Światowej Organizacji Zdrowia (WHO, World Health Organization) wynika, że w 2020 roku depresja będzie jedną z głównych przyczyn niepełnosprawności i drugim najczęstszym rozpoznaniem po chorobach układu krążenia [8, 9]. Lęk to stan emocjonalny wywołany czynnikami wewnętrznymi organizmu lub zewnętrznymi, który poprzedza zagrożenie, dlatego istotna jest akceptacja choroby przez pacjenta, a zwłaszcza zaakceptowanie swojej osoby w roli chorego, często do końca życia $[10,11]$.

Choroba nowotworowa często budzi lęk i niepokój, ponieważ zazwyczaj jest zjawiskiem niespodziewanym, niejednokrotnie nieodwracalnym, często o nieznanej etiologii i zagrażającym życiu [12]. Część pacjentów kojarzy chorobę nowotworową z bólem i działaniami niepożądanymi leczenia, takimi jak utrata włosów i wymioty, co może wywołać reakcje emocjonalne, głównie stanów lękowych [13]. Dokładna ocena zaburzeń depresyjnych i lęku może zapewnić skuteczną pomoc chorym i poprawić wyniki leczenia [14]. Przedłużający się stan smutku i negatywne myślenie mogą skutkować brakiem chęci do walki z chorobą nowotworową. Rozpoznanie raka piersi i raka jelita grubego jest często źródłem stresu, który towarzyszy pacjentowi od chwili przekazania informacji o rozpoznaniu do zakończenia leczenia, a niejednokrotnie dłużej. Często stres związany z procesem leczenia nie znika, lecz utrzymuje się i niekiedy nasila po zakończeniu leczenia przeciwnowotworowego. Reakcja na chorobę nowotworową jest uzależniona od indywidualnych cech osobowościowych, takich jak umiejętność radzenia sobie w sytuacjach stresowych. Postawa wobec choroby, stopień zaufania personelowi medycznemu i zaakceptowanie zaproponowanego leczenia oraz poziom akceptacji choroby stanowią czynniki wpływające na samopoczucie chorych i powodzenie terapii [15].

Celem badania było zweryfikowanie hipotezy badawczej, która zakłada, że w miarę wzrostu poziomu akceptacji choroby, maleje poziom lęku i depresji.

\section{Materiał i metody}

Badania przeprowadzono w okresie 1 września 2019-31 grudnia 2019 roku wśród chorych z rozpoznaniem rakiem jelita grubego i raka piersi, hospitalizowanych na Oddziale Onkologii w celu stosowania chemioterapii. Na przeprowadzenie badania uzyskano zgodę Komisji Bioetycznej, które przeprowadzono zgodnie z Deklaracją Helsińską. Kryteria włączenia do badania obejmowały rozpoznanie raka piersi lub raka jelita grubego, wiek od 18 lat, dobrowolną i świadomą zgodę na udział w badaniu. Kryteria wyłączenia stanowiły rozpoznanie inne niż rak piersi lub jelita grubego, brak dobrowolnej zgody na udział w badaniu, ciężki stan ogólny. Badanie miało charakter ankietowy, wszystkich chorych poinformowano o celu, metodzie i możliwości rezygnacji na każdym etapie badania. Do badania zakwalifikowano 100 pacjentów, przy czym po weryfikacji odrzucono 20 chorych z powodu nieprawidłowo wypełnionych ankiet. Do analizy zakwalifikowano 80 pacjentów: 40 kobiet z rozpoznaniem raka piersi i 40 mężczyzn z rozpoznaniem raka jelita grubego. Zastosowano następujące narzędzia badawcze:

- Skala Przystosowania Psychicznego do Choroby Nowotworowej (Mini-MAC) autorstwa Watson i wsp. - służy ona do oceny reakcji pacjenta na rozpoznanie choroby nowotworowej i zmian zachodzących podczas procesu leczenia i rehabilitacji. Narzędzie składa się z 29 stwierdzeń, które mierzą 4 strategie radzenia sobie $z$ chorobą nowotworową: duch walki, zaabsorbowanie lękowe, pozytywne przewartościowanie i bezradność beznadziejność. Dwie z czterech strategii to styl 
konstruktywny, a dwie pozostałe - styl destrukcyjny. Ze względu na uzyskanie wyników stanów lękowych i depresyjnych w pracy brano pod uwagę jedynie dwie z czterech strategii: zaabsorbowanie lękowe i bezradność — beznadziejność [16];

- Skala akceptacji choroby (AIS, Acceptance of Inness) autorstwa Felton i wsp. w adaptacji Juczyńskiego - służy ona do oceny stopnia akceptacji schorzenia w przewlekłych jednostkach chorobowych. Skala ta obejmuje 8 pytań dotyczących negatywnych skutków złego stanu zdrowia pozwalających na ocenę akceptacji ograniczeń spowodowanych przez sytuację zdrowotną, wyniki mieszczą się w zakresie 8-40 punktów. Wysoki wynik oznacza akceptację choroby, natomiast im niższy wynik, tym akceptacja choroby jest mniejsza [17];

- Inwentarz Depresji Becka (BDI, Beck Deprssion Inventory) autorstwa Becka i wsp. - jest to narzędzie samoopisowe i służy do przesiewowego rozpoznania objawów depresji u osoby badanej i obejmuje 21 pozycji, wyniki są klasyfikowane w 4 kategoriach: 1 - brak depresji, 2 - depresja łagodna, 3 - depresja umiarkowana, 4-depresja ciężka. Inwentarz Depresji Becka jest narzędziem do pomiaru nasilenia depresji u pacjentów w psychiatrii [18];

- autorska ankieta - metryczka służyła do zebrania podstawowych informacji o pacjentach: wieku, płci, wykształcenia i miejsca zamieszkania.

\section{Metody statystyczne}

Do analizy wyników zastosowano analizę korelacji, a obliczone współczynniki korelacji Pearsona poddano weryfikacji testem $t$-Studenta. Jako zmienną niezależną uwzględniono poziom akceptacji choroby (AIS), natomiast zmiennymi zależnymi były miary lęku i depresji, których poziomy ustalono na podstawie wybranych narzędzi badawczych. Ponadto, obliczano wartości średnie i odchylenia standardowe (SD, standard deviation) oraz dokonano klasyfikacji wyników zgodnie z obowiązującymi normami dla zastosowanych skal.

\section{Wyniki}

Charakterystykę socjodemograficzną badanych chorych przedstawiono $w$ tabeli 1 . Wiek mężczyzn $z$ rozpoznaniem raka jelita grubego mieścił się $w$ zakresie 22-85 lat, średnia 57,6 \pm 14,6 lat, natomiast kobiet z rozpoznaniem raka piersi 21-74 lat, średnia $48,4 \pm 13,4$ lat. Większość mężczyzn mieszkała na wsi (40\%), natomiast $37,5 \%$ kobiet mieszkało w mieście 50-100 tys. mieszkańców. W grupie chorych na raka jelita grubego wykształcenie zawodowe posiadało $32,5 \%$ mężczyzn, a wykształcenie wyższe $27,5 \%$ mężczyzn. Spośród chorych na raka piersi wykształcenie średnie posiadało $27,5 \%$ kobiet, a wykształcenie wyższe $42,5 \%$ kobiet. Ponad 35\% mężczyzn i 30\% kobiet było $\mathrm{w}$ związku małżeńskim, w stanie wolnym pozostawało 20\% mężczyzn i 27,5\% kobiet, 72,5\% mężczyzn i $65 \%$ kobiet zadeklarowało, że posiada dzieci. W grupie mężczyzn 42,5\% uznało swoją sytuację finansową jako wystarczającą, natomiast $45 \%$ kobiet uznało, że ich sytuacja finansowa jest zła. Największe wsparcie ze strony otoczenia otrzymali mężczyźni $(32,5 \%)$, natomiast najwięcej kobiet uzyskało wsparcie od przyjaciół $(27,5 \%)$.

W tabeli 2 przedstawiono dane kliniczne badanych chorych. Pacjenci z rozpoznaniem raka jelita grubego byli hospitalizowani na Oddziale Onkologii 11-20 razy (30\%), taki sam odsetek mężczyzn (30\%) zadeklarował, że obecnie jest ponad 20 raz na Oddziale Onkologii, w celu podania chemioterapii. Po raz pierwszy na Oddział Onkologii zostało przyjętych 35\% kobiet. Trzydzieści pięć procent mężczyzn zadeklarowało, że choroba trwa 13-24 miesiące, natomiast poniżej 5 miesięcy okresu trwania choroby zgłosiło 37,5\% kobiet. Wśród mężczyzn ból często odczuwało 37,5\%, od czasu do czasu $35,5 \%$ chorych. U większości kobiet $(57,5 \%)$ często występowały dolegliwości bólowe, najczęściej wywołane przez obrzęk chłonny (52,5\%). Trudności w codziennym funkcjonowaniu odczuwało $82,5 \%$ mężczyzn, w grupie kobiet problem ten zgłaszato $85 \%$ kobiet, natomiast obniżony nastrój towarzyszył $45 \%$ mężczyzn i 57,5\% kobiet. Częsty stan niepokoju i lęku zadeklarowało $42,5 \%$ mężczyzn, 25\% uznało, że ten stan występuje od czasu do czasu. U większości $(52,5 \%)$ kobiet stan niepokoju i lęku występował często. Mężczyźni (95\%) i kobiety $(87,5 \%)$ otrzymali dokładne informacje dotyczące chemioterapii.

Chemioterapię stosowano u 37,5\% mężczyzn i u $60 \%$ kobiet. Mężczyźni byli często niespokojni (35\%) i smutni (40\%), w zakresie lęku udzielili równomiernie odpowiedzi: nie boję się (30\%), często się boję (30\%) i przeżywam stale lęk (30\%), natomiast kobiety stale były niespokojne $(40 \%)$, często smutne (35\%) i stale przeżywały lęk $(37,5 \%)$.

W tabeli 3 przedstawiono charakterystykę poziomu akceptacji choroby przez ankietowanych (AIS). Niski poziom akceptacji choroby wykazało 52,5\% mężczyzn, natomiast $w$ grupie kobiet niski poziom akceptacji wystąpił u $85 \%$ badanych. Średnią akceptację choroby wykazało $20 \%$ mężczyzn i $10 \%$ kobiet, natomiast wysoki poziom akceptacji choroby wykazało $27,5 \%$ mężczyzn i 5\% kobiet. Ogólny poziom akceptacji choroby wyniósł w grupie mężczyzn średnio 21,5 $\pm 9,1$, wśród kobiet wartość średnia wyniosła 13,8 \pm 5,8. 
Tabela 1. Dane socjodemograficzne ankietowanych chorych

\begin{tabular}{|c|c|c|c|}
\hline \multirow{2}{*}{$\begin{array}{l}\text { Charakterystyka } \\
\text { Wiek }\end{array}$} & \multicolumn{2}{|c|}{ Rak jelita grubego } & \multirow{3}{*}{$\begin{array}{l}\text { Rak piersi } \\
48,4 \\
13,4\end{array}$} \\
\hline & 57,6 & \multirow{2}{*}{$\begin{array}{l}\text { Min.--maks. } \\
\text { 22-85 }\end{array}$} & \\
\hline 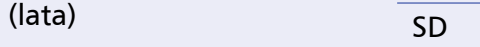 & 14,6 & & \\
\hline & $\mathrm{n}$ & $\%$ & $\mathbf{n}$ \\
\hline \multicolumn{4}{|l|}{ Miejsce zamieszkania } \\
\hline Wieś & 16 & $40,0 \%$ & 13 \\
\hline Miasto $<50$ tys. & 9 & $22,5 \%$ & 3 \\
\hline Miasto $50-100$ tys. & 10 & $25,0 \%$ & 15 \\
\hline Miasto $>100$ tys. & 5 & $12,5 \%$ & 9 \\
\hline \multicolumn{4}{|l|}{ Wykształcenie } \\
\hline Podstawowe & 6 & $15,0 \%$ & 5 \\
\hline Zawodowe & 13 & $32,5 \%$ & 7 \\
\hline Średnie & 10 & $25,0 \%$ & 11 \\
\hline Wyższe & 11 & $27,5 \%$ & 17 \\
\hline \multicolumn{4}{|l|}{ Stan cywilny } \\
\hline Panna/kawaler & 8 & $20,0 \%$ & 11 \\
\hline Mężatka/żonaty & 14 & $35,0 \%$ & 12 \\
\hline Rozwiedziona/rozwiedziony & 9 & $22,5 \%$ & 9 \\
\hline Wdowa/wdowiec & 9 & $22,5 \%$ & 8 \\
\hline \multicolumn{4}{|l|}{ Dzieci } \\
\hline Tak & 29 & $72,5 \%$ & 26 \\
\hline Nie & 11 & $27,5 \%$ & 14 \\
\hline \multicolumn{4}{|l|}{ Liczba dzieci } \\
\hline 1 & 10 & $34,5 \%$ & 14 \\
\hline $2-3$ & 12 & $41,4 \%$ & 8 \\
\hline $4-5$ & 7 & $24,1 \%$ & 4 \\
\hline$>5$ & 0 & $0,0 \%$ & 0 \\
\hline \multicolumn{4}{|l|}{ Wiek dzieci } \\
\hline$<10$ lat & 5 & $17,2 \%$ & 8 \\
\hline $11-19$ lat & 4 & $13,8 \%$ & 8 \\
\hline 20-29 lat & 2 & $6,9 \%$ & 3 \\
\hline$>29$ lat & 18 & $62,1 \%$ & 7 \\
\hline \multicolumn{4}{|l|}{ Sytuacja mieszkaniowa } \\
\hline Mieszkam sama/sam & 18 & $45,0 \%$ & 13 \\
\hline Mieszkam z dziećmi & 3 & $7,5 \%$ & 13 \\
\hline Mieszkam z żoną/mężem & 7 & $17,5 \%$ & 3 \\
\hline Mieszkam z rodziną & 12 & $30,0 \%$ & 11 \\
\hline \multicolumn{4}{|l|}{ Sytuacja finansowa } \\
\hline Zła & 13 & $32,5 \%$ & 18 \\
\hline Wystarczająca & 17 & $42,5 \%$ & 11 \\
\hline Dobra & 5 & $12,5 \%$ & 6 \\
\hline Bardzo dobra & 5 & $12,5 \%$ & 5 \\
\hline \multicolumn{4}{|l|}{ Wsparcie ze strony otoczenia } \\
\hline Od rodziny & 9 & $22,5 \%$ & 9 \\
\hline Od przyjaciół & 3 & $7,5 \%$ & 11 \\
\hline Od partnera/partnerki & 5 & $12,5 \%$ & 4 \\
\hline Od członków zespołu medycznego & 5 & $12,5 \%$ & 6 \\
\hline Wszystkie z powyższych & 13 & $32,5 \%$ & 7 \\
\hline Nie mam wsparcia & 5 & $12,5 \%$ & 3 \\
\hline
\end{tabular}


Tabela 2. Charakterystyka kliniczna ankietowanych chorych

\begin{tabular}{|c|c|c|c|c|c|c|c|}
\hline \multirow[t]{2}{*}{ Charakterystyka } & \multicolumn{2}{|c|}{$\begin{array}{l}\text { Rak jelita } \\
\text { grubego }\end{array}$} & \multirow{2}{*}{$\begin{array}{l}\text { Rak } \\
\text { piersi } \\
\text { n }\end{array}$} & \multirow[t]{2}{*}{ Charakterystyka } & \multicolumn{2}{|c|}{$\begin{array}{l}\text { Rak jelita } \\
\text { grubego }\end{array}$} & \multirow{2}{*}{$\begin{array}{l}\text { Rak } \\
\text { piersi } \\
\text { n }\end{array}$} \\
\hline & $\mathbf{n}$ & $\%$ & & & $\mathbf{n}$ & $\%$ & \\
\hline \multirow{2}{*}{\multicolumn{3}{|c|}{$\begin{array}{l}\text { Częstość pobytu na Oddziale Onkologii i } \\
\text { Hematoonkologii }\end{array}$}} & & Nigdy & 4 & $10,0 \%$ & 1 \\
\hline & & & & Często & 17 & $42,5 \%$ & 21 \\
\hline $1 \mathrm{raz}$ & 3 & $7,5 \%$ & 14 & Przez większość czasu & 6 & $15,0 \%$ & 11 \\
\hline $2-5$ razy & 7 & $17,5 \%$ & 3 & Od czasu do czasu & 10 & $25,0 \%$ & 7 \\
\hline 6-10 razy & 6 & $15,0 \%$ & 5 & Nigdy & 7 & $17,5 \%$ & 1 \\
\hline 11-20 razy & 12 & $30,0 \%$ & 8 & \multirow{2}{*}{\multicolumn{3}{|c|}{$\begin{array}{l}\text { Otrzymanie dokładnych informacji dotyczą- } \\
\text { cych leczenia chemioterapią }\end{array}$}} & \\
\hline$>20$ razy & 12 & $30,0 \%$ & 10 & & & & \\
\hline \multicolumn{4}{|c|}{ Czas trwania choroby onkologicznej } & Tak & 38 & $95,0 \%$ & 35 \\
\hline$<5$ miesięcy & 11 & $27,5 \%$ & 15 & Nie & 2 & $5,0 \%$ & 5 \\
\hline 5-12 miesięcy & 6 & $15,0 \%$ & 6 & \multirow{2}{*}{\multicolumn{3}{|c|}{$\begin{array}{l}\text { Rodzaj leczenia w przebiegu nowotworu } \\
\text { piersi/jelita grubego }\end{array}$}} & \\
\hline 13-24 miesiące & 14 & $35,0 \%$ & 6 & & & & \\
\hline$>24$ miesiące & 9 & $22,5 \%$ & 13 & Leczenie chirurgiczne & 13 & $32,5 \%$ & 10 \\
\hline \multirow{2}{*}{\multicolumn{3}{|c|}{$\begin{array}{l}\text { Częstość występowania dolegliwości bólo- } \\
\text { wych }\end{array}$}} & & Radioterapia & 3 & $7,5 \%$ & 0 \\
\hline & & & & Hormonoterapia & 1 & $2,5 \%$ & 1 \\
\hline Często & 15 & $37,5 \%$ & 23 & Immunoterapia & 0 & $0,0 \%$ & 0 \\
\hline Przez większość czasu & 7 & $17,5 \%$ & 3 & Chemioterapia & 15 & $37,5 \%$ & 24 \\
\hline Od czasu do czasu & 14 & $35,0 \%$ & 13 & Terapia skojarzona & 8 & $20,0 \%$ & 5 \\
\hline Nigdy & 4 & $10,0 \%$ & 1 & \multicolumn{4}{|c|}{ Reakcja na dotychczasowe leczenie } \\
\hline \multicolumn{4}{|c|}{ Rodzaj dolegliwości w raku piersi } & Bardzo dobra & 5 & $12,5 \%$ & 3 \\
\hline \multicolumn{2}{|l|}{$\begin{array}{l}\text { Powiększenie węzłów chłon- } \\
\text { nych }\end{array}$} & & 14 & Dobra & 20 & $50,0 \%$ & 5 \\
\hline \multicolumn{3}{|l|}{ Owrzodzenie skóry piersi } & 3 & Zła & 11 & $27,5 \%$ & 28 \\
\hline \multicolumn{3}{|l|}{ Wyciek z brodawki } & 0 & Bardzo zła & 4 & $10,0 \%$ & 4 \\
\hline \multicolumn{3}{|l|}{ Obrzęk limfatyczny } & 21 & \multicolumn{4}{|l|}{ Stosunek do spokoju } \\
\hline \multicolumn{3}{|l|}{ Nerwobóle } & 1 & Jestem spokojna/spokojny & 13 & $32,5 \%$ & 1 \\
\hline \multicolumn{3}{|l|}{ Wszystkie z powyższych } & 1 & $\begin{array}{l}\text { Często jestem niespokojna/ } \\
\text { niespokojny }\end{array}$ & 14 & $35,0 \%$ & 12 \\
\hline \multicolumn{3}{|l|}{ Inne } & 0 & Stale jest niespokojna/niespo- & 8 & $20,0 \%$ & 16 \\
\hline \multicolumn{3}{|l|}{ Brak dolegliwości } & 0 & kojny & & & \\
\hline \multicolumn{4}{|c|}{ Rodzaj dolegliwości w raku jelita grubego } & Cały czas jestem niespokojna/ & 5 & $12,5 \%$ & 11 \\
\hline Zaparcia/biegunki & 1 & $2,5 \%$ & & niespokojny & & & \\
\hline Bóle w dole brzucha & 0 & $0,0 \%$ & & Stosunek do smutku & & & \\
\hline Nudności/wymioty & 6 & $15,0 \%$ & & Nie jestem smutna/smutny & 13 & $32,5 \%$ & 2 \\
\hline Wszystkie z powyższych & 0 & $0,0 \%$ & & Odczuwam często smutek & 16 & $40,0 \%$ & 14 \\
\hline Inne & 0 & $0,0 \%$ & & Przeżywam stale smutek, od & 6 & $15,0 \%$ & 13 \\
\hline Brak dolegliwości & 33 & $82,5 \%$ & & & & & \\
\hline Trudności w codziennym fun & onov & aniu & & $\begin{array}{l}\text { Jestem cały czas smutny i jest } \\
\text { to nie do wytrzymania }\end{array}$ & 5 & $12,5 \%$ & 11 \\
\hline Tak & 33 & $82,5 \%$ & 34 & Stosunek do lęku & & & \\
\hline Nie & 7 & $17,5 \%$ & 6 & Nie boję się & 12 & $30,0 \%$ & 3 \\
\hline Częstość występowania smut & go $n$ & stroju & & Często się boję & 12 & $30,0 \%$ & 8 \\
\hline Często & 18 & $45,0 \%$ & 23 & Przeżywam stale lęk & 12 & $30,0 \%$ & 15 \\
\hline Przez większość czasu & 5 & $12,5 \%$ & 8 & Silny lęk towarzyszy mi cały & 4 & $10,0 \%$ & 14 \\
\hline Od czasu do czasu & 13 & $32,5 \%$ & 8 & czas & & & \\
\hline
\end{tabular}


Tabela 3. Charakterystyka poziomu akceptacji choroby prze ankietowanych chorych

\begin{tabular}{llll} 
Skala & \multicolumn{2}{l}{ Rak jelita grubego } & Rak piersi \\
& $n$ & $\%$ & $n$ \\
\hline Niski (8-18) & 21 & $52,5 \%$ & 21 \\
\hline Średni (19-28) & 8 & $20,0 \%$ & 8 \\
\hline Wysoki (29-40) & 11 & $27,5 \%$ & 11 \\
& $\begin{array}{l}\text { Ogólny poziom } \\
\text { akceptacji choroby } \\
\text { Wartość }\end{array}$ & SD & Wartość \\
& $\begin{array}{l}\text { średnia } \\
\text { 21,5 }\end{array}$ & 9,1 & 13,8 \\
\hline
\end{tabular}

Tabela 4. Charakterystyka poziomu depresji według Inwentarza Depresji Becka (BDI)

\begin{tabular}{llll}
\hline Skala & \multicolumn{2}{l}{ Rak jelita grubego } & Rak piersi \\
& $n$ & $\%$ & $n$ \\
\hline $\begin{array}{l}\text { Brak depresji } \\
\text { (0-10) }\end{array}$ & 16 & $40,0 \%$ & 1 \\
\hline $\begin{array}{l}\text { Depresja łagod- } \\
\text { na (11-19) }\end{array}$ & 6 & $15,0 \%$ & 1 \\
\hline $\begin{array}{l}\text { Depresja umiar- } \\
\text { kowana (20-25) }\end{array}$ & 10 & $25,0 \%$ & 2 \\
\hline $\begin{array}{l}\text { Depresja ciężka } \\
\text { (26-63) }\end{array}$ & 8 & $20,0 \%$ & 36 \\
\hline & $\begin{array}{l}\text { Ogólny poziom } \\
\text { depresji } \\
\text { Wartość }\end{array}$ & SD & $\begin{array}{l}\text { Wartość } \\
\text { średnia }\end{array}$ \\
& 16,7 & 11,2 & 34,4 \\
\hline
\end{tabular}

W tabeli 4 przedstawiono charakterystykę poziomu depresji według BDI. W grupie mężczyzn depresji nie stwierdzono u 40\%, depresję łagodną u 15\%, depresję umiarkowaną u 25\% i depresję ciężką u 20\% chorych, wartość średnia poziomu depresji wyniosła $16,7 \pm 11,2$. Wśród kobiet ciężką depresję stwierdzono u $90 \%$, u $2,5 \%$ badanych wykazano brak depresji, wartość średnia wyniosła $34,4 \pm 7,8$. Brak depresji może świadczyć o tymczasowym pogorszeniu stanu psychicznego pacjenta, który spowodowany jest bieżącymi wydarzeniami w życiu.

W tabeli 5 przedstawiono wartości średnie i odchylenia standardowe dla wybranych strategii Skali Mini-MAC. W grupie chorych na raka jelita grubego wartości średnie w zaabsorbowaniu lękowym wyniosły $18,13 \pm 5,69$, bezradności - beznadziejności $16,95 \pm 6,03$, stylu destrukcyjnego $35,08 \pm 11,53$, natomiast $w$ grupie kobiet $\mathrm{z}$ rozpoznaniem raka piersi wartości średnie zaabsorbowania lękowego
Tabela 5. Wartości średnie i odchylenia standardowe dla wybranych strategii skali Mini-MAC

\begin{tabular}{llll} 
& $\begin{array}{l}\text { Zaabsor- } \\
\text { bowanie } \\
\text { lękowe }\end{array}$ & $\begin{array}{l}\text { Bezrad- } \\
\text { ność } \\
\text { - bezna- } \\
\text { dziejność }\end{array}$ & $\begin{array}{l}\text { Styl } \\
\text { destruk- } \\
\text { cyjny }\end{array}$ \\
Rak jelita grubego & & \\
\hline Wartość średnia & 18,13 & 16,95 & 35,08 \\
\hline SD & 5,69 & 6,03 & 11,53 \\
\hline Rak piersi & & & \\
\hline Wartość średnia & 26,00 & 22,63 & 48,63 \\
\hline SD & 3,02 & 2,28 & 5,13 \\
\hline
\end{tabular}

Tabela 6. Wyniki analizy korelacji między poziomem akceptacji choroby (AIS) i poziomem lęku i depresji

\begin{tabular}{llcl} 
Skala & \multicolumn{2}{l}{ Poziom akceptacji choroby (AIS) } \\
& Rak jelita & & Rak piersi \\
& $r$ & $p$ & $r$ \\
\hline $\begin{array}{l}\text { Zaabsorbowanie } \\
\text { lękowe (Mini } \\
\text {-MAC }\end{array}$ & $-0,611$ & $<0,001$ & $-0,720$ \\
\hline $\begin{array}{l}\text { Bezradność - } \\
\text { beznadziejność } \\
\text { (Mini-MAC) }\end{array}$ & $-0,615$ & $<0,001$ & $-0,768$ \\
\hline $\begin{array}{l}\text { Styl destrukcyjny } \\
\text { (Mini-MAC) }\end{array}$ & $-0,624$ & $<0,001$ & $-0,766$ \\
\hline Becka (BDI) & $-0,603$ & $<0,001$ & $-0,622$ \\
\hline
\end{tabular}

wyniosły $26 \pm 3,02$, bezradności - beznadziejności $22,6 \pm 2,28$, stylu destrukcyjnego $48,63 \pm 5,13$.

W tabeli 6 przedstawiono wyniki analizy korelacji charakteryzujące związek pomiędzy stopniem akceptacji choroby a depresją i lękiem występujących wśród pacjentów z rozpoznaniem raka piersi oraz jelita grubego. Wszystkie wyznaczone współczynniki korelacji są ujemne, a poziom znamienności wynosi $p<0,001$.

\section{Dyskusja}

W przeprowadzonym badaniu w zakresie analizy korelacji związku pomiędzy stopniem akceptacji choroby a depresją i lękiem wśród chorych z rozpoznaniem raka piersi i jelita grubego wszystkie współczynniki korelacji były ujemne i statystycznie istotne $(p<0,001)$. Ponadto stwierdzono, że im wyższy jest stopień akceptacji choroby, tym chorzy lepiej radzą sobie z depresją i lękiem. Pacjenci z niskim poziomem akceptacji choroby nowotworowej, zwłaszcza podczas leczenia o znacznej toksyczności, wymagają intensywnych działań terapeutycznych. Niektórzy pacjenci akceptują rozpoznanie, jednak zdecydowana większość potrzebuje czasu na 
przyjęcie i przystosowanie do choroby nowotworowej. Uzyskane wyniki potwierdzają hipotezę badawczą, że w miarę wzrostu poziomu akceptacji choroby, spada poziom lęku i depresji. Ponadto stwierdzono, że kobiety z rozpoznaniem raka piersi silniej doświadczają stanów depresyjnych i lękowych w porównaniu z mężczyznami z rozpoznaniem raka jelita grubego. Wysoki wynik depresji w grupie kobiet może wynikać z działań nieporządanych leków cytostatycznych (m.in. złe samopoczucie, mdłości, wymioty, utrata włosów, zaparcia, biegunki). W zakresie stopnia akceptacji choroby ocenianej skalą AIS, która opisuje negatywne konsekwencje złego stanu zdrowia pacjenta, zarówno u mężczyzn z rozpoznaniem raka jelita grubego, jak i u kobiet z rozpoznaniem raka piersi, stwierdzono niski poziom akceptacji choroby, co oznacza poczucie dyskomfortu psychicznego, brak samowystarczalności i obniżenie poczucia własnej wartości [19]. Depresja umiarkowana, którą stwierdzono $u$ badanych chorych, sugeruje podjęcie działań terapeutycznych, natomiast depresja ciężka, którą stwierdzono u $90 \%$ kobiet leczonych z powodu raka piersi, stanowi istotny problem kliniczny, zagrożenie zdrowia i życia, zwłaszcza, kiedy pojawiają się myśli samobójcze. Niezbędna jest wówczas szybka pomoc psychiatryczna, leczenia farmakologiczne i hospitalizacja [20]. Zaabsorbowanie lękowe odzwierciedla niepokój wywołany chorobą nowotworową, która w ocenie chorych stanowi zagrożenie, a sygnały pochodzące $z$ organizmu interpretowane są jako pogorszenie stanu zdrowia. Wyniki w zakresie strategii bezradność - beznadziejność wskazują na bezsilność pacjentów, która może powodować zagubienie i bierne poddanie chorobie [21].

Choroba nowotworowa może wywoływać lęk i niedowierzanie wśród chorych i ich najbliższych. Lokalizacja nowotworu, na przykład pierś u kobiet i następstwa leczenia, sztuczny odbyt u chorych na raka jelita grubego, często skutkuje dyskomfortem u kobiet i u mężczyzn; są to istotne czynniki, które powodują dodatkowe obciążenie psychiczne chorych na nowotwory [22]. Zaburzenia psychiczne mogą wystąpić na każdym etapie leczenia [23], a częstą reakcją na informację o chorobie nowotworowej jest wystąpienie zaburzeń lękowych i depresyjnych [24].

Brak wiedzy na temat choroby nowotworowej może powodować nierealistyczny obraz choroby, niekiedy kojarzonej ze śmiercią. Dominować może również postawa ochrony przed trudnymi informacjami i niedopuszczania ich do świadomości, czemu mogą towarzyszyć szok, lęk, niedowierzanie czy złość, które zmniejszają zasoby energetyczne organizmu, niezbędne dla zachowania homeostazy. Chorzy i bliscy powinni mieć zapewnioną możliwość dostępu do psychologa - psychoonkologa, który może zapewnić wsparcie pacjentom i opiekunom.
Stany lękowe stanowią istotny element psychologicznej autoanalizy choroby nowotworowej. Uczucia te mogą negatywnie wpływać na życie i zdrowie pacjenta w sytuacji, kiedy informacja o chorobie jest wypierana, nieakceptowana przez chorego, a pojawiające się negatywne myśli i nastawienie emocjonalne w przebiegu choroby mogą niekiedy przybierać formę zaburzeń depresyjnych, na przykład myśli samobójczych [25]. Brak apetytu, zmęczenie, wahania nastroju czy bezsenność mogą stanowić objawy rozwijającej się depresji [26]. Depresja jest często rozpoznawana u chorych przewlekle i z rozpoznaniem choroby nowotworowej [27].

De Walden-Gałuszko i wsp. w badaniu przeprowadzonym u 1100 chorych na nowotwory wykazali, że u jednej trzeciej pacjentów wystąpiły zaburzenia depresyjne, a u 44,9\% wystąpił zespół depresyjno-lękowy dezadaptacyjny, natomiast u 17,7\% pacjentów ciężka depresja. Zaburzenia depresyjne, które wystąpiły w badanej grupie pacjentów, występowały najczęściej u kobiet i u osób młodych [28]. Szwat i wsp. stwierdzili występowanie depresji i stanów granicznych depresji u 30\% chorych na nowotwory objętych opieką paliatywną [29]. Istotnym elementem jest akceptacja choroby. Zaakceptowanie choroby przez pacjenta jest etapowe i bywa bardzo trudne. Zauszniewski i wsp. uznali akceptację choroby za psychiczne pogodzenie i dostosowanie do potencjalnych ograniczeń, prowadzące do ingerencji zmienionej kondycji psychofizycznej z dotychczasowym stylem życia [30].

Ograniczenia przeprowadzonego badania stanowią niewielka liczba badanych chorych z rozpoznaniem jedynie dwóch nowotworów (rak piersi i rak jelita grubego), objęcie badaniem niejednorodnej grupy pacjentów pod względem stopnia zaawansowania klinicznego choroby nowotworowej, a także różny odsetek mężczyzn i kobiet leczonych cytostatykami. Innym ograniczeniem przeprowadzonego badania był brak analizy wpływu płci na uzyskane wyniki w zakresie depresji.

\section{Wnioski}

1. Wykazano ujemne korelacje pomiędzy poziomem akceptacji choroby a lękiem i depresją.

2. Kobiety z rakiem piersi wykazują częściej niski poziom akceptacji choroby.

3. Poziom depresji i lęku jest wyższy u kobiet z rakiem piersi, w porównaniu z mężczyznami z rozpoznaniem raka jelita grubego.

\section{Konflikt interesów}

Autorka deklaruje brak konfliktu interesów.

\section{Finansowanie}

Badanie nie było finansowane. 


\section{References}

1. Potrykowska A, Strzelecki Z, Szymborski J, Witkowski J. Zachorowalność i umieralność na nowotwory a sytuacja demograficzna Polski. Rządowa Rada Ludnościowa, Warsaw 2014.

2. Zdrowie priorytetem politycznym państwa - analiza i rekomendacje. Report of the Institute for Health Protection, Warsaw 2013.

3. Wyrwicz L, Gryglewicz J, Chrostowski Sz, Domańska-Sadynica M, Ambroziewicz B. Sytuacja pacjenta z jelitem grubego w Polsce - propozycja zmian. Warsaw 2013.

4. Didkowska J, Wojciechowska U. Nowotwory złośliwe w Polsce w 2013 roku. Centre of Oncology - M. SkłodowskaCurie Institute, Warsaw 2015.

5. http://onkologia.org.pl/nowotwory-zlosliwe-jelita-grubego-c18-21 (25 March 2020).

6. http://onkologia.org.pl/nowotwory-zlosliwe-piersi-c18 (25 March 2020).

7. Święcicki Ł. Depresje - definicja, klasyfikacje, przyczyny. Psychiatria w Praktyce Ogólnolekarskiej. 2002;(2): 151-159.

8. Mess E, Malewicz K, Lisowska A, et al. Występowanie depresji u pacjentów z nowotworem płuc. Onkol Pol. 2006;(9): 154-157.

9. Nowicki A, Rządkowska B. Depresja i lęk u chorych z nowotworami złośliwymi. Współcz Onkol. 2005;(9): 396-403.

10. Bilikiewicz A. ed. Psychiatria. PZWL, Warsaw 2006: 222594.

11. Wrona-Polańska H. Zmiana samopercepcji w procesie adaptacji w chorobie o niepomyślnej prognozie. Sztuka Leczenia. 1998;(4): 67-75.

12. Małyszczak K, Wróbel T, Mazur G, et al. Objawy lękowe i depresyjne u pacjentów leczonych na nowotwory hematologiczne. Psychiatria Pol. 2005;(39): 33-41.

13. Tomaszewska I. Psychologiczne aspekty depresji w chorobach nowotworowych. Psychoonkologia. 2000;(7): 9-18.

14. Mess E, Głuszyńska M, Lisowska A, et al. Ocena poziomu bólu i lęku u pacjentów z chorobą nowotworową. Onkol Pol. 2009;(12): 154-161.

15. Juczyński Z. Narzędzia pomiaru w promocji i psychologii zdrowia. Pracownia Testów Psychologicznych Polskiego Towarzystwa Psychologicznego, Warsaw 2001: 168-174.

16. Mini-Mac - Skala Przystosowania Psychicznego do Choroby Nowotworowej. Watson M., Law M., dos Santos M., Greer S., Baruch J., Bliss J., 167-168.

17. Juczyński Z. Narzędzia pomiaru w promocji i psychologii zdrowia. Pracownia Testów Psychologicznych Pol- skiego Towarzystwa Psychologicznego, Warsaw 2001: 168-174.

18. Beck AT, Ward CH, Mendelson M, et al. An Inventory for Measuring Depression. Archives of General Psychiatry. 1961; 4(6): 561, doi: 10.1001/archpsyc.1961.01710120031004.

19. Juczyński Z. Narzędzia pomiaru w promocji i psychologii zdrowia. Pracownia Testów Psychologicznych Polskiego Towarzystwa Psychologicznego, Warsaw 2001: 168-170.

20. Beck AT, Ward CH, Mendelson M, et al. An inventory for measuring depression. Arch Gen Psychiatry. 1961;(4): 53-63, doi: 10.1001/archpsyc.1961.01710120031004, indexed in Pubmed: 13688369.

21. Mini-Mac - Skala Przystosowania Psychicznego do Choroby Nowotworowej. Watson M., Law M., dos Santos M., Greer S., Baruch J., Bliss J., 168-178.

22. De Walden-Gałuszko KaG, Majkowicz M, Trzebiatowska I. Najczęstsze problemy psychiczne $w$ ambulatoryjnej praktyce onkologicznej. Psychoonkologia. 1998;(2): 21-26.

23. Araszkiewicz A, Bartkowiak W, Starzec W. Zaburzenia lękowe w chorobie nowotworowej. Psychiatria w Praktyce Ogólnolekarskiej. 2004;(4): 157-166.

24. Tomaszewska I. Psychologiczne aspekty depresji w chorobach nowotworowych. Psychoonkologia. 2000;(7): 9-18.

25. Fryc-Martyńska J. Wsparcie społeczne jako forma pomocy w procesie zmagania się z krytycznymi wydarzeniami życiowymi. Wolontariusze Polskiego Towarzystwa Opieki nad Chorymi ze Stomią POL-ILKO. Psychoonkologia. 1997;(14): 99-102.

26. Guthrie E. Emotional disorder in chronic illness: psychotherapeutic interventions. Br J Psychiatry. 1996; 168(3): 265-273, doi: 10.1192/bjp.168.3.265, indexed in Pubmed: 8833678.

27. Katon WJ. Epidemiology and treatment of depression in patients with chronic medical illness. Dialog Clin Neuroscie. 2011; 13(1): 7-23, indexed in Pubmed: 21485743.

28. De Walden-Gałuszko W, Majkowicz M, Zdun-Ryżewska A. Zaburzenia przystosowania do choroby nowotworowej - trudności diagnostyczne zespołów depresyjnych. Psychoonkol. 2013;(1): 10-15.

29. Szwat B, Słupski W, Krzyżanowski D. Sposoby radzenia sobie $z$ chorobą nowotworową, a poczucie depresji i nasilenie bólu u chorych objętych opieka paliatywną. Piel Zdr Publ. 2011;(1): 35-51.

30. Zauszniewski JA, Bekhet AK, Lai CY, et al. Effects of teaching resourcefulness and acceptance on affect, behavior, and cognition of chronically ill elders. Issues Ment Health Nurs. 2007; 28(6): 575-592, doi: 10.1080/01612840701354547, indexed in Pubmed: 17613157. 